Article

\title{
Supply Chains' Failure in Workers' Rights with Regards to the SDG Compass: A Doughnut Theory Perspective
}

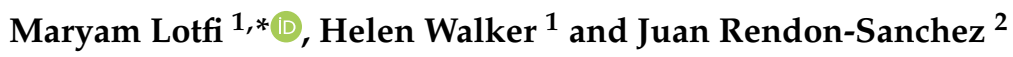 \\ 1 Department of Logistics and Operations Management, Cardiff Business School, Cardiff University, \\ Cardiff CF10 3EU, UK; walkerhl@cardiff.ac.uk \\ 2 SITE, Department of Management, Business School, University of Exeter, Exeter EX4 4ST, UK; \\ j.rendon-sanchez@exeter.ac.uk \\ * Correspondence: Lotfim@cardiff.ac.uk
}

Citation: Lotfi, M.; Walker, H.; Rendon-Sanchez, J. Supply Chains' Failure in Workers' Rights with Regards to the SDG Compass: A Doughnut Theory Perspective. Sustainability 2021, 13, 12526. https://doi.org/10.3390/ su132212526

Academic Editors:

Beatriz Aibar-Guzmán,

Cristina Aibar-Guzmán and Olaf Weber

Received: 30 September 2021 Accepted: 10 November 2021 Published: 12 November 2021

Publisher's Note: MDPI stays neutral with regard to jurisdictional claims in published maps and institutional affiliations.

Copyright: (c) 2021 by the authors. Licensee MDPI, Basel, Switzerland. This article is an open access article distributed under the terms and conditions of the Creative Commons Attribution (CC BY) license (https:// creativecommons.org/licenses/by/ $4.0 /)$.

\begin{abstract}
Many supply chains have pledged to prevent the violation of workers' rights as part of social sustainability in their far-flung supply chains. This paper provides a way to understand why supply chains fail to overcome the violation of workers' rights by mapping the UN SDGs onto the social foundations of the doughnut model, with respect to workers' rights in supply chains. We develop the sustainable supply chain doughnut model with regards to the SDGs, through which we investigate workers' rights violations. Examples from both UK-based and world-wide supply chains illustrates our conceptual model. Supply chains have shortfalls in all aspects of the social foundation when it comes to workers as one of their main stakeholders. Until supply chains are successful in overcoming shortfalls across all elements of the social foundation, moving to the next layer of the doughnut framework is impossible, which is the safe and just space for all humans, including workers. This 'safe and just space' seems out of reach despite international efforts such as the SDGs. The resulting conceptual model can be the foundation for descriptive, instrumental, and normative research on workers' rights in the supply chain as part of the social sustainability.
\end{abstract}

Keywords: workers' rights; SDG; doughnut theory; supply chain; social sustainability

\section{Background}

Sustainable supply chain management (SSCM) has become mainstream in both research and practice over the last two decades. However, we are still witnessing many incidents of supply chains experiencing non-socially and non-environmentally sustainable issues. The planet's ability to provide natural resources is running out, and at the same time many stakeholders are demanding action on a range of issues from climate change to working conditions in supplier factories in developing countries [1]. A number of world events and trends have influenced the context for social SSCM, most recently the COVID-19 pandemic, and also the trends towards outsourcing and global supply chains.

The COVID-19 pandemic has illuminated how unsustainable our supply chains are in managing social issues. The pandemic has resulted in world economic losses of 9 trillion dollars and additional unemployment of 305 million people globally, with labour in the informal economy hit even worse-Around 1.6 billion workers are expected to lose their livelihood [2]. Many western brands such as ASOS, C\&A, Edinburgh Woolen Mill, Gap and Primark have used the COVID-19 pandemic as an excuse to pass more risk on to suppliers, demanding greater discounts and leaving suppliers unable to negotiate. This has led to large numbers of garment workers being laid off, potentially leading to them taking exploitive jobs, being the victims of forced labour, or putting their children to work to cope with the economic loss. Another example of social issues in supply chains to arise during the pandemic concerns gloves supplied to the NHS in UK from Malaysian suppliers, where employees were working without social distancing during national lockdowns [3]. A final example is that the pandemic has put additional pressures on supply chain workers 
involved in manufacturing essential medical equipment [4]. The COVID-19 pandemic and its expected economic repercussions may change the assumed prioritisation of economic sustainability amongst the triple-bottom-line dimensions, highlighting the significant problems that SSCM faces, especially when confronted with disruptive shocks [2].

\section{Literature Review}

The development of social sustainability in supply chains has received less attention in the literature [5-7]. It is defined as the management of practices, capabilities, stakeholders and resources to address human potential and welfare, both within and outside the communities of the supply chain [8,9]. Within the supply chain, it affects safety, health, hygiene, wages, and labour rights, along with education and housing of the people who are part of the supply chain, but it also makes companies responsible for their suppliers regarding stakeholders (consumers, local community, NGOs etc.) [5,7,10]. Reference [11] refers to the first category as basic practices and the second one as advanced practice. Furthermore, social sustainability is measured based on social performance, including human rights, gender diversity, community development, product responsibility, health and safety management and decent work (wages and working hours) [8].

The context for social SSCM has also been influenced by the outsourcing trend, which has shifted intensive production activities to countries with lower labour costs. The complex supply chain configurations involved in the use of many suppliers across different tiers and countries have led to limited visibility. These trends have led to increasing transgression in social sustainability in the supply chain. With increased outsourcing and globally dispersed production facilities, social problems and workers' rights violations are no longer interorganizationally rooted, b5dut are also affected by different actors of the supply chain [12] Forced labour leads to illegal profit of $\$ 150$ bn in private enterprises, highlighting the dark side of the reality of today's supply chains [13]. Some well-known cases include child labour in the West African cocoa industry [14] or children as young as eight picking coffee beans in Guatemala for Starbucks [15].

Finally, the context for social SSCM has been influenced by globalization. Global supply chains power $80 \%$ of world trade, but also play a significant role in worker's rights violations in developing countries [16]. The transformation of global supply chains has created both opportunities and challenges for workers [17]. While more employment opportunities are provided, there are violations of workers' rights that, despite the endeavors of different actors in the supply chains and other stakeholders, are reported daily [18]. Researchers tend to analyse only aspects of the problem rather than considering the picture in its entirety, due to the many different actors involved and the complexity of the relationships in global supply chains. While recent research has broadened understanding of the treatment of workers in global supply chains, different factors prevent progress, including the complexity of global supply chains, multiple political and economic trade-offs and the lack of good data on critical issues [18-20].

\subsection{Motivation for Study}

This study aims to make several contributions to the field of SSCM. First, social issues have received less attention than environmental issues in SSCM, and we seek to focus on workers' rights in supply chains [9]. Second, adopting theory in SSCM is still in it's infancy, and we bring the doughnut theory lens to investigate workers' rights in the supply chain [21]. Third, we explore social SSCM at different levels, as we consider the UN sustainable development goals (SDGs) at an international level, and how they have been applied and interpreted at an inter-organisational level in supply chains. Specifically, there is little previous research exploring how workers' rights are represented in the UN SDGs, and are implemented in supply chains, so we seek to make a contribution to knowledge in this area. 


\subsection{Problem Statement}

In this paper, we explore a specific aspect of social SSCM, namely the violation of workers' rights in the supply chain. We define workers' rights according to ILO conventions in terms of forced labour, child labour, discrimination, trade union rights and worker committees, wages, working times, health and safety, and legally binding employment relationships. We explore workers' rights in supply chains in the context of the UN SDGs, by adopting a doughnut theory lens.

We ask the following research questions:

- How do the UN SDGs map onto the social foundations of the doughnut model, with respect to workers' rights in supply chains?

- With each element of the social foundations of the doughnut model, what issues arise concerning the violations of workers' rights in supply chains?

The paper elaborates on the doughnut theory in Section 3. It then links the SDGs to the doughnut theory in Section 4. Section 5 investigates why supply chains fail to support workers' rights and provides different examples. Section 6 proposes a sustainable supply chain doughnut model with regards to the SDGs, and concludes that the social foundation elements of doughnut theory with regards to the SDGs in the context of supply chains at present falls short in terms of workers' rights.

\section{Doughnut Theory}

Doughnut theory was proposed by [22] and offers a framework for thinking about how we create a world in which humanity thrives. The theory combines the concept of a social foundation with that of an ecological ceiling in a single framework, as shown in Figure 1.

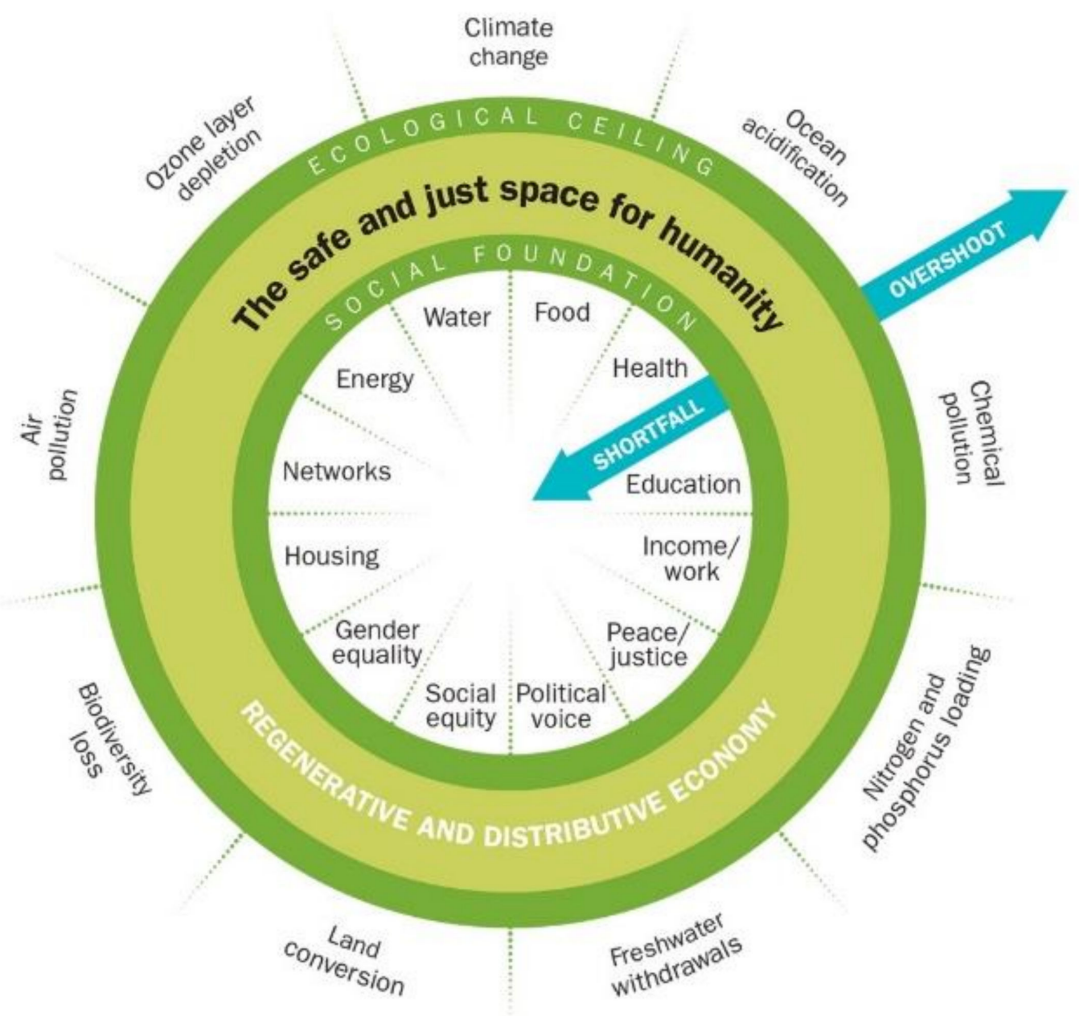

Figure 1. The classic image of the Doughnut framework with social and planetary boundaries. Source: Doughnut (economic model) [22].

The doughnut's inner ring is the social foundation which sets out the basic needs in life, on which no one should be left falling short. These 12 basics include: sufficient 
food, clean water, access to energy and clean cooking facilities, access to education and to healthcare, decent housing, a minimum income and decent work, access to a network of information and to a network of social support, gender equality, social equality, political voice, and peace and justice.

The ecological ceiling shown by the outer circle includes nine planetary boundaries developed by environmental scientists [23] that represent the planet's critical life supporting systems and their capacity. To preserve them, humanity must live within these ecological boundaries while meeting the basic needs described in the social foundation. Between the social foundation and the ecological ceiling lies a space in which it is possible to meet the needs of all people within the means of the living planet-an ecologically safe and socially just space in which humanity can thrive.

To our knowledge there has been no previous research that applies this mid-level theory to sustainability in the supply chain. We take the doughnut theory lens for this research as we think it provides a good match for sustainability issues in supply chains, while highlighting both aspects of social and environmental. The space between the social foundation and the ecological ceiling is where supply chains should move into from both sides simultaneously.

\section{SDGs through a Doughnut Theory Lens}

In 2015, the United Nations General Assembly adopted the Sustainable Development Goals (SDGs), which constitute the centerpiece of the 2030 Agenda for Sustainable Development. The agenda's 17 core goals are broken down into 169 associated targets to direct global development strategy until 2030. While the SDGs emerged from the human development process of the Millennium Development Goals (MDGs) and the sustainable development Rio+ process, they also substantially expanded the range and depth of topics covered and signaled the necessity of a shift in governance strategies [23].

The first generation of attempts to structure SDGs systematically by categorizing them according to their main intended outcomes was inspired by the doughnut framework [23]. For example, few categorizations have grouped SDG1 and 2 as basic needs [24,25]. In Table 1, we map the SDGs with a social focus onto doughnut theory social foundation elements. For completeness, we also show the more environmentally focused SDGS, which relate more to the ecological ceiling, and will not be the focus of this paper. In our mapping, SDGs 11 and 12 are categorized in the ideal layer.

Table 1. SDGs with a social focus onto doughnut theory social foundation elements.

\begin{tabular}{|c|c|c|}
\hline Section below in the Paper & Doughnut Theory Social Foundation Elements & Social Focused SDGs \\
\hline 5.1 & Basic needs: water, food, energy, housing & 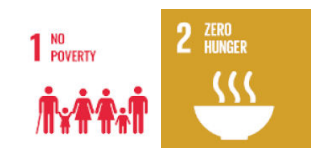 \\
\hline 5.2 & Health & 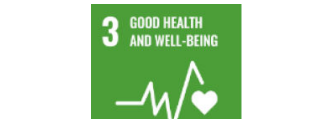 \\
\hline 5.3 & Education & \\
\hline 5.4 & Income and work & 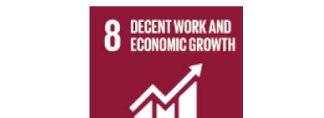 \\
\hline
\end{tabular}


Table 1. Cont.

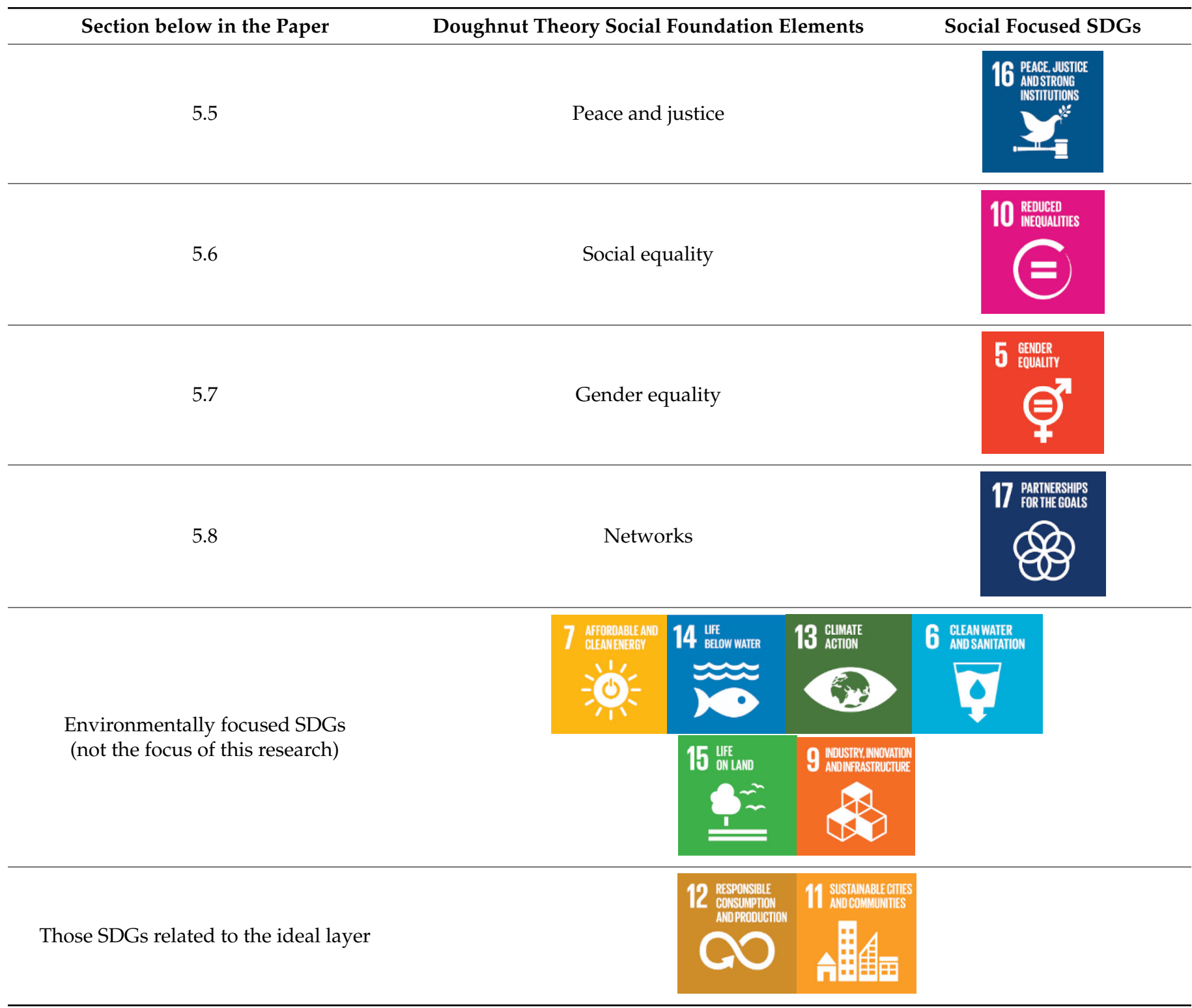

\section{Exploring Workers' Rights in Supply Chains with Regards to SDGs with Doughnut Theory Lens}

Taking the doughnut theory, we investigate different elements of the social foundation to explore how supply chains are performing with respect to workers' rights. We cover each of the elements in the order they are presented in Table 1 and cover key issues and give examples for each. Where possible, we provide examples of workers' rights violations in the context of the COVID-19 pandemic, to show how this may have exacerbated social issues in supply chains.

\subsection{Basic Needs (Water, Food, Housing, Energy) \\ 5.1.1. Key Issues}

In supply chains, providing decent conditions in terms of workers' basic needs is not a priority. The priority is the low-cost production of products to maximise profit [26]. This is not just occurring in developing countries where there is limited visibility of suppliers, but also occurs within Europe. 


\subsubsection{Examples}

The Spanish farming province of Almeria exports $61 \%$ of its production to Europe and the UK, and migrant workers are paid below minimum wage and live in squalor. The workers work under difficult conditions during the daytime, while at night they live in encampments without electricity or sanitation [27].

In the pandemic context, Tönnies, a slaughterhouse and meat producer, shut down one of its plants in the Western part of Germany in June 2020 after more than 1500 workers were found to be infected with COVID-19 [28]. Low temperature and crowded working conditions have made meatpacking plants global COVID-19 hotspots [29]. The treatment of workers at Tönnies has been criticized for years, but the pandemic opened the investigation of these issues [30]. For instance, labour unions have criticized Tönnies for having "catastrophic working conditions" and politicians have argued that workers pay the price for cheap meat [31].

In both these examples, there were clear "workers" rights violations" in terms of "unsafe working conditions" [32]. Workers were generally presented with unsafe conditions, as it was not possible to ensure proper social distancing [33,34]. Many eastern European agency workers lived in cramped accommodation organised by the sub-contractors who had brought them into the country, under conditions that made social distancing impossible [35].

\subsection{Health}

\subsubsection{Key Issues}

To deal with fiercely competitive business environments, organizations very often seek to focus on their core competencies and achieve considerable cost savings by outsourcing some of their products and services to suppliers [36]. To meet increasing buying firms' demands for better business deals, involving cost reduction, higher order flexibility, and shorter lead time, suppliers under pressure, particularly those benefiting from weak regulatory environments, often turn to unethical actions, some of which can amount to modern slavery practices, such as child labour, forced labour, and health and safety issues [37]. The sad fact remains that in terms of health and safety and workers' rights, employees in some industries and countries are far less likely to come home at the end of the day's work uninjured, or indeed at all, as the following example illustrates.

\subsubsection{Examples}

The collapse of the Rana Plaza building in Bangladesh which housed five readymade garment factories producing clothes for major western brands (such as Primark and Benetton) [38] in 2013, killing 1132 people and injuring more than 2500, highlighted the size of the danger and hazards facing workers from suppliers' unethical actions (e.g., lack of health and safety and poor working conditions) [37].

In the pandemic context, there was a spike in cases of COVID-19 in July 2020 in Leicester garment factories in the UK [39]. Many factories continued to operate during lockdown and some without proper social distancing and not standard conditions. An estimated $75-80 \%$ of clothes produced in the city were to the supply the online fashion label Boohoo. Despite the spike in cases, factories remained open, and workers were forced to work throughout the lockdown for less than minimum wage. Additionally, workers were working under unsafe conditions. A textile factory worker reported that they were working with no gloves, no masks, and no social distancing, and up to 40 workers would touch a single garment as it went around the garment factory [40].

\subsection{Education}

\subsubsection{Key Issues}

In many cases, workers accept badly paid and unsafe working conditions because they have lacked opportunities for education and alternative sources of employment [41]. 


\subsubsection{Examples}

In the mining of mica for the cosmetics and paint industries [42] in India, children as young as six are paid 50 rupees a day (approx. 70 cents), with child labour making up half of all workers in mica mines. They are often the only bread winners in the family and stopping mining mica or boycotting the product would force these regions further into poverty. Instead, working with parents and children is key to help them understand the opportunities and skills provided by education and training, to enable them to find employment elsewhere.

\subsection{Work and Income}

\subsubsection{Key Issues}

Providing workers with decent work and a proper income is not being fulfilled in many supply chains. Imprecise terms such as 'reasonable lead time' or 'fair wages' should be avoided, and precise terms for minimum wage and maximum working hours should be used. Contracts fail to fully account for the morally salient features of the employment [43].

\subsubsection{Example}

The UK's biggest modern slavery gang supplied the nation's biggest supermarkets Tesco, Asda, Waitrose, Sainsbury and M\&S. Sainsbury and M\&S all bought vegetables from firms that hired men and women brought into the UK [44]. More than 450 Polish workers were entrapped and were forced to work, some working for as little as 50p a day.

\subsection{Peace and Justice}

Exploitation in supply chains is often exemplified by sweatshop labour, involving unsafe work for long hours at low wages. Democratic principles of justice should apply to supply chains and different tiered suppliers [45], rather than the parent firm downstream taking advantage of underlying injustices in the supply chain [41] for economic advantage. One way to pursue justice is to have clear and fair contracts among supply chain actors. Different approaches have been used in the supply chain contracts [46-48], though each have their own deficiencies. This is more apparent as we go further down the chain and the parent firms lose the control and visibility over other tier suppliers.

An example of injustice in supply chains is that many western brands, such as ASOS, C\&A, Edinburgh Woolen Mill, Gap and Primark, used COVID-19 to dump more risk on suppliers or demand discounts, leaving suppliers unable to negotiate. This lead to huge numbers of garment workers being laid off, with a substantial potential for them to return to exploitive jobs, being victims of forced labour, or putting their children to work to cope with the economic loss [49]. In this aspect there are different actors playing crucial roles.

\subsubsection{Government}

Key Issues

Where supply chain participants are located in democratically governed political regimes, attention to workers' related issues are more likely. When we consider the influence of governments on workers' rights outcomes, we must be attentive to both government capacity (are they able to protect workers? Do they have the resources to identify and address violations of labour rights?) and governments' willingness to act (does the government choose given its own interest, to protect the rights of labour, sometimes at the expense of employer?). Capacity matters only when a will to protect rights also exists, such as the case of China and the unwillingness of the central government to allow the formation of independent unions $[50,51]$. Violations frequently occur where host countries have weak legal protection systems with indirect support of corruption or oppressiveness in some cases [52]. 
Examples

The largest rubber glove manufacturing company is Top Glove, with an annual revenue of $£ 870 \mathrm{~m}$ and based in Malaysia. It produces gloves for multiple brands, supplying NHS Supply Chain, the organisation that provides a $40 \%$ share of medical goods purchased by NHS hospitals and clinics. In 2018 and 2019 there were reports by the Guardian and Diplomat accusing both companies of routine modern slavery. The company went for denial in 2018 [53].

With the pressure of the pandemic, labour abuses continue. According to the Guardian and the Telegraph, factories have been operating at 100\% capacity since 1 April 2020 . Lobbying by the Malaysian Rubber Glove Manufacturers Association throughout March was supported by both the EU and the UK in communications that appeared to make no mention of forced labour concerns.

Therefore, acting against violation of workers' rights is not easy, with the potential for action at the government level to backfire. In dynamic times, governments simply give priority to their own nations rather than thinking of the issues globally. Other stakeholders (in this case doctors) care enough to do something about a situation that is unethically and illegally supported by governments, so other stakeholders can be the voice of workers.

\subsubsection{NGOs}

Key Issues

Emerging social conflicts between corporate actions and societal expectations gave rise to an entirely new type of NGO in two ways: one that their activities challenge a company or industry's core business operations, and two, that they sought remedies that would call for new standards of corporate governance and accountability, such as Oxfam. Another example is a mediating NGO, where the new type of NGO doesn't act as the corporate critic or adversary, but instead seeks to bridge the gap between the companies and their adversaries, such as Fair Labour Association (FLA) and Social Accountability International (SAI). Thus, in undertaking such a role, the NGO must depend to a large extent on the resources and cooperation of the company, therefore undermining its own independence and credibility. As an example, the labour monitoring NGOs, FLA and SAI, were reported to encourage goal displacement during their struggle to eliminate worker abuse and sweatshop-like working conditions in subcontractor facilities. Therefore, instead of being the voice of workers, sometimes the actions of other stakeholders are supporting brands and corporates.

Examples

Monitoring does not work well in reality, as factory operators may falsifying the records that auditors see [16], opening only certain factory floors for inspection, and handpicking the workers that auditors can interview. There is evidence that NGOs that have a strong corporate influence, like FLA, are more likely to monitor minimal labour standards such as pay, and health and safety. These NGOs are unwilling to criticize their corporate partners who provide them with the funds needed to support their operations [16].

\subsubsection{International Labour Organization (ILO) and World Trade Organization (WTO)}

\section{Key Issues}

The ILO acts to set norms and standards through its conventions, and to provide some technical assistance to national governments. However, its material resources are limited in terms of directly enforcing its rules [50].

The World Trade Organization (WTO) is the second-best organization for the governance of labour related issues. Therefore, the WTO can avoid conflicts between developed and developing country members, and while developed countries governments have increasingly come to link workers' rights with market access via preferential trade agreements, workers' related conditions in trade agreements often are motivated more by the need to gain domestic support for agreements than by a concern about workers abroad [50]. 
Examples

The ILO and the WTO are part of the UN family of organisations. They have quite advanced ethical supply policies, as outlined by the UN procurement division, in part due to the nature of the broader work of the UN. For example, UN organisations will not buy from suppliers that use child labour, or that are involved with the production of landmines, as it counters the work done by UNICEF and the UN High Commission for Refugees. However, how one investigates such policies beyond the first tier of suppliers remains a challenge.

\subsubsection{Unions}

\section{Key Issues}

Freedom of association remains a persistent challenge, and for this issue, there is no substitute for effective government enforcement of national labour laws [54]. Independent labour unions do not exist in many production locations, and workers who attempt to create or join unions are dismissed from employment [51]. Governments may provide the legal rights to organize, but fail to enforce this right in practice.

\section{Examples}

In Bangladesh, due to tight connections between political elites and factory owners, there are huge limitations on the legal protection and the practical voice of workers. While union members have the right to directly participate in the inspection process, not all factories have union representatives and despite pressures from US and EU to have a greater union presence, many union locals are still denied registration, with many members continuing to report dismissal, intimidation and physical harm [50].

\subsection{Social Equality}

5.6.1. Key Issues

Unfortunately, in current global supply chains, global socioeconomic inequalities and deprivations are prevalent [41]. Social inequality in supply chains is especially prevalent in certain industries (e.g., cocoa and mining) and countries (e.g., India, Africa), and often affects children.

\subsubsection{Examples}

The Congo in Africa is the main producer of copper and cobalt, accounting for twothirds of the global supplies of the metals, which are used in smart phones and electric car batteries, and has a long-lasting history of child slavery in the industry, with around $15 \%$ of children aged 5-17 engaged in child labour. Economic problems mean that mining workers are more likely to take their children to work. The dynamic environment leads to a lack of information on those that are vulnerable. Families facing economic difficulties can lead to children entering modern slavery [55].

\subsection{Gender Equality}

\subsubsection{Key Issues}

Current trends for holding supply chains and businesses responsible for gender equality are limited by a lack of focus on sexual harassment and sexual violence when it comes to women as workers in supply chains [56]. Supply chains may choose to ignore, or attempt to co-opt, the human rights agenda. Migrant women are among the most vulnerable people in supply chains during the pandemic [57].

\subsubsection{Examples}

In Spain, around 7200, mostly female, Moroccan seasonal workers were employed in the province of Huelva for the strawberry harvest. These workers are faced with unsafe working conditions that have escalated during the first wave of the COVID-19 pandemic [54]. Once the harvest was finished and the contracts of the workers expired, 
most of the workers found themselves trapped, as their home country had closed its borders. In the middle of this crisis, many of the women gave birth during their stay in Spain, working until the day before, if not the same day, they went into labour. Women were experiencing new forms of exploitation as the industry was hit by labour shortages caused by the pandemic [58].

\subsection{Networks}

\subsubsection{Key Issues}

Empirical evidence of collaboration and communication along global supply chains is scant. The complexity of supply chains might mean that buyers or final consumers do not know who the suppliers or sub-suppliers are. Communication is prevented by increasing complexity and fragmentation of a chain or of one single actor in a chain [59]. While the complex and global nature of modern supply chains makes tackling workers' rights violations difficult for firms acting alone, companies need to go beyond their boundaries and try different approaches, even including collaborations with their competitors [60].

Outsourcing in supply chains leads to a need for reliable, comprehensive, verified, and credible information about workers' rights within the chain, however, getting such information is extremely difficult. It requires independent and disinterested information providers, and verification agents and platforms that make this information available and transparent for all supply chain actors [59]. The more transparent the supply chains are, the less governance challenges are presented. However, a necessary precondition is actual and reliable information on suppliers, and suppliers of suppliers, and the rest of tiers up to the production points [28].

\subsubsection{Examples}

The Ivory Coast and Ghana are two West African countries that together produce about $65 \%$ of the worlds' cocoa, and it is an enduring situation that more than 2 million children work in the sector. In the pandemic context, schools were being closed and NGO monitors were unable to access villages in the cocoa harvest season. Lack of information of what exactly was happening in villages were making those children more vulnerable. Therefore, effective communication and collaborative strategies need to be designed that are contingent even in periods disruption to have the real voice of specifically those in points of production for the supply chains [61].

\section{Discussion and Conclusions}

The manifold deterioration of our environment seems to be anchored largely at the bias of an economic model that favours monetary gain and its own perpetuation, rather than environmental or social considerations. This is manifested in the permanent disregard for workers or environmental safety in practice and also, perhaps, in more publications addressing the economic and environmental aspects than the social ones (in an SSCM literature review [62] the greatest number of studies consider the economic dimension (1019), followed by environmental (779), and the least number pursue the social dimension (222)).

We have different crises interacting with each other today. The social and environmental crises interact in ways already known in general lines: environmental degradationsome of it with industrial causes-pushes migration, which in turn creates pools of workers desperate to work in dangerous conditions after being displaced. The displacement in turn creates belts of poverty in large cities, exacerbating the social crisis by the multiplication of crime and the menaces of precarity. Neglect and incapacity of local governments of such areas drives environmental degradation. And while these crises unfold and exacerbate, there is still reluctance to accept that companies need to be restrained.

Such reluctance has its roots. From an historic perspective, the bias towards monetary gain is coupled with an idea that is key in the dominant economic model that took off in the 1970s: that of freedom. According to the precepts of neo-liberalism, "The sanctity of 
contracts and the individual right to freedom of action, expression, and choice must be protected. The state must therefore use its monopoly of the means of violence to preserve these freedoms at all costs. By extension, the freedom of businesses and corporations (legally regarded as individuals) to operate within this institutional framework of free markets and free trade is regarded as a fundamental good." [63]

Therefore, many of the disasters we witness today in production systems scattered around the world can be understood as materialisations of the deeply-rooted belief that companies are exercising their freedom. This is reflected in the clear lack of enforceable international regulation mostly addressed by soft law mechanisms such as voluntary guidelines, corporate codes of conduct, and multi stakeholder initiatives [62] that prevents supply chains eliminating the shortfalls.

The doughnut model proposes a scheme with a core (peace/justice, political voice, social equity, gender equality, etc.), upon which a fair economy can be established. And having a fair supply chain is part of having a fair economy. This is overarching thinking that has restrain inbuilt.

This article has highlighted the dimensions of failure in social terms. We sought to explore the violation of workers' rights in the supply chain. First, we investigated how the UN SDGs map onto the social foundations of the doughnut framework. We then took each element of the social foundation and considered the key issues and examples associated with the violation of workers' rights, particularly in the context of the COVID-19 pandemic. Despite the aims of the UN SDGs, it seems that supply chains continue to fail workers and neglect their rights. We identified shortfalls in all aspects of the social foundation when it comes to workers as one of the main stakeholders in supply chains. Whilst our examples were purposively selected to illustrate some of the key issues, they present a damning picture of how workers' rights are currently not being addressed in supply chains. The disregard for workers' rights is reflected in research as well as practice.

\subsection{Contribution to Theory}

We have sought to identify overlaps between the social foundations of the doughnut framework, and the social aspects of the SDGs. To our knowledge, there are no previous studies linking doughnut theory and SDGs in an SSCM context. Furthermore, we have sought to add flesh to the bones of the social foundation part of the doughnut model, by considering the context of workers' rights for each element in turn, adding key issues and examples. This is an example of theory elaboration $[62,63]$ where a conceptual model exists but details need to be filled in. From our study, it seems that until supply chains are successful in overcoming shortfalls across all elements of the social foundation, moving to the next layer of the doughnut framework is impossible, which is the safe and just space for all humans including workers. This 'safe and just space' - where sustainable supply chains should be located-seems out of reach despite international efforts such as the SDGs. We therefore propose the sustainable supply chain doughnut model with regards to the SDGs based on this research and adopted from the work of Raworth [22].

Therefore, we are proposing that sustainable supply chains should be examined though the doughnut model with an environmental ring as the upper ceiling (maximum threshold) and social ring as inner edge of the doughnut (minimum threshold), with the space between being where real sustainable supply chains should be placed. Furthermore, despite the greater focus on the environmental aspect, we believe a more comprehensive and systemic starting point should be to focus on the interaction between humans and the environment. Figure 2 presents the sustainable supply chain doughnut model with regards to the SDGs, based on the doughnut economic framework of Raworth. Based on our analysis, we have identified that supply chains have shortfalls on all aspects of the social ring. 


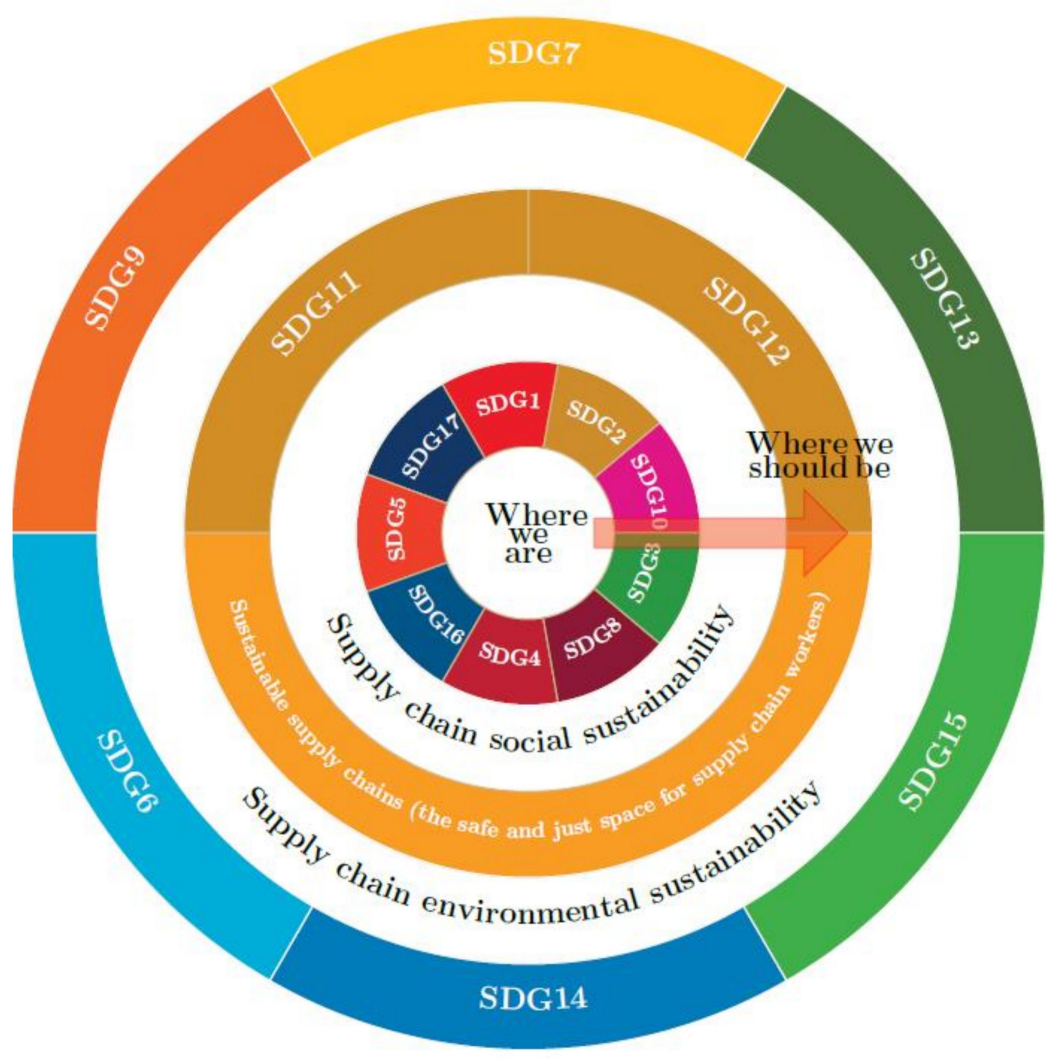

Figure 2. The sustainable supply chain doughnut model with regards to the SDGs, based on the doughnut economic framework of Raworth. (The Figure has been drawn in Tex Live 2020 and GPL Ghostscript 9.27 softwares).

\subsection{Contribution to Practice}

Organisations operate in a dynamic context, and the recent pandemic has illustrated the pressures on supply chains and reveals more starkly how economic goals have dominance over social issues in supply chains. It seems the social SCM landscape is changing. With increasing stakeholder pressures, such as attention from consumers and the media, and governments and NGOs, organisations need to be aware (or be seen to be aware?) of how their supplier's suppliers are treating their employees. Increasingly, modern slavery issues are passing into law, and international organisations are introducing clearer social goals (e.g., SDGs) and more stringent procurement policies. The risk of exposure of violations of workers' rights is becoming greater, so it seems to be good risk management strategy to be aware of such issues and act. It also would appear to be the right thing to do, if global workers are to occupy the 'safe and just space' suggested by the doughnut framework.

\subsection{Limitations and Future Research}

This study was selective in its examples and did not conduct full case studies to provide primary and secondary data to illustrate the violations of workers' rights. Instead, examples were sought from the media. Part of the methodological challenge here is one of social desirability bias, as few organisations would welcome researchers in to scrutinize such social issues in supply chains. In addition, the pandemic prevented any primary data collection from occurring. The availability of good secondary data on the violation of workers' rights is also scant.

Given these challenges, future research could explore each aspect of the social foundation in more depth, to compare industries and countries in their response to, for example, gender equality. There is also a resonance between the doughnut model and other models 
that have explored basic human needs, such as Maslow's hierarchy of needs (1943), which could be further explored. The prioritisation of environmental over social issues in the doughnut model is also worthy of exploration, as it belies the dominance of economic issues that pervade. Future research could also investigate the role of key stakeholders in influencing workers' rights, such as exploring how influential organisations have operationalised the UN SDGs, or the role of NGOs and government. Such studies could adopt the stakeholder or power dependency theory to explore the dynamics between influential actors in the supply chain. Finally, focusing on cases where workers' rights are protected would be a welcome avenue for future research, and provide examples to organisations seeking to improve social issues in their supply chains.

Future work should look for more encompassing studies, examining the interaction of the environmental, economic, and human aspects. Such encompassing studies should be conducted in a context where the impossibilities of our current economic system to deliver the 'safe and just space' in sustainable supply chains are acknowledged. One strong route is research on redistributive and regenerative supply chains, how they can be theorized and how they can be brought into practice.

Author Contributions: Conceptualization, M.L. and J.R.-S.; methodology, M.L. and H.W.; software, J.R.-S.; writing—original draft preparation, M.L.; writing—review and editing, M.L., H.W., J.R.-S.; All authors have read and agreed to the published version of the manuscript.

Funding: This research received no external funding.

Conflicts of Interest: The authors declare no conflict of interest.

\section{References}

1. Pagell, M.; Shevchenko, A. Why research in sustainable supply chain management should have no future. J. Supply Chain. Manag. 2014, 50, 44-55. [CrossRef]

2. Trautrims, A.; Schleper, M.C.; Cakir, M.S.; Gold, S. Survival at the expense of the weakest? Managing modern slavery risks in supply chains during COVID-19. J. Risk Res. 2020, 23, 1067-1072. [CrossRef]

3. Lovett, Government Continued to Source PPE from Malaysia Suppliers Accused of Modern Slavery, the Independent. Available online: https:/ /www.independent.co.uk/news/health/covid-ppe-gloves-malaysia-nhs-government-latest-b1812320.html (accessed on 6 September 2021).

4. Miller, F.A.; Young, S.B.; Dobrow, M.; Shojania, K.G. Vulnerability of the medical product supply chain: The wake-up call of COVID-19. BMJ Qual. Saf. 2021, 30, 331-335. [CrossRef] [PubMed]

5. D'Eusanio, M.; Zamagni, A.; Petti, L. Social sustainability and supply chain management: Methods and tools. J. Clean. Prod. 2019, 235, 178-189. [CrossRef]

6. Huq, F.A.; Chowdhury, I.N.; Klassen, R.D. Social management capabilities of multinational buying firms and their emerging market suppliers: An exploratory study of the clothing industry. J. Oper. Manag. 2016, 46, 19-37. [CrossRef]

7. Croom, S.; Vidal, N.; Sceptic, W.; Marshall, D.; McCarthy, L. Impact of social sustainability orientation and supply chain practices on operational performance. Int. J. Oper. Prod. Manag. 2018, 38, 2344-2366. [CrossRef]

8. Nakamba, C.C.; Chan, P.W.; Sharmina, M. How does social sustainability feature in studies of supply chain management? A review and research agenda. Supply Chain Manag. Int. J. 2017, 22, 522-541. [CrossRef]

9. Sodhi, M.S.; Tang, C.S. Corporate social sustainability in supply chains: A thematic analysis of the literature. Int. J. Prod. Res. 2018, 56, 882-901. [CrossRef]

10. Khan, S.A.; Mubarik, M.S.; Kusi-Szarpong, S.; Zaman, S.I.; Alam Kazmi, S.H. Social sustainable supply chains in the food industry: A perspective of an emerging economy. Corp. Soc. Responsib. Environ. Manag. 2021, 28, 404-418. [CrossRef]

11. Marshall, D.; McCarthy, L.; McGarth, P.; Claudy, M.C. Going above and beyond: How sustainability culture and entrepreneurial orientation drive social sustainability supply chain practice adoption. Supply Chain Manag. Int. J. 2015, 20, 434-454. [CrossRef]

12. Hofmann, H.; Schleper, M.C.; Blome, C. Conflict minerals and supply chain due diligence: An exploratory study of multi-tier supply chains. J. Bus. Ethics 2018, 147, 115-141. [CrossRef]

13. ILO. World Employment Social Outlook. 2018. Available online: https://www.ilo.org/wcmsp5/groups/public/---dgreports/--dcomm/---publ/documents/publication/wcms_615594.pdf (accessed on 20 September 2021).

14. Ange Aboa, A.R. Child Labour Rising in West Africa Cocoa Farms Despite Efforts: REUTERS. 2020. Available online: https: / / www.reuters.com/article/uk-cocoa-childlabour-ivorycoast-ghana-idUKKBN2742FU (accessed on 5 September 2021).

15. Doward, J. Children as Young as Eight Picked Coffee Beans on Farms Supplying Starbucks. Available online: https://www. theguardian.com/business/2020/mar/01/children-work-for-pittance-to-pick-coffee-beans-used-by-starbucks-and-nespresso (accessed on 5 September 2021).

16. Bird, R.C.; Soundararajan, V. From suspicion to sustainability in global supply chains. Tex. AML Rev. 2019, 7, 383. [CrossRef] 
17. Egels-Zandén, N.; Lindholm, H. Do codes of conduct improve worker rights in supply chains? A study of Fair Wear Foundation. J. Clean. Prod. 2015, 107, 31-40. [CrossRef]

18. Anner, M. Monitoring workers' rights: The limits of voluntary social compliance initiatives in labor repressive regimes. Glob. Policy 2017, 8, 56-65. [CrossRef]

19. Schleper, M.C.; Stanczyk, A.; Blome, C. Archetypes of Global Sourcing Decision-Making: The Influence of Contextual Factors. In Proceedings of the Academy of Management 2018, Chicago, IL, USA, 10-14 August 2018; Academy of Management: Briarcliff Manor, NY, USA, 2018; p. 10510.

20. Berliner, D.; Greenleaf, A.R.; Lake, M.; Levi, M.; Noveck, J. Governing global supply chains: What we know (and don't) about improving labor rights and working conditions. Annu. Rev. Law Soc. Sci. 2015, 11, 193-209. [CrossRef]

21. Mani, V.; Gunasekaran, A.; Delgado, C. Supply chain social sustainability: Standard adoption practices in Portuguese manufacturing firms. Int. J. Prod. Econ. 2018, 198, 149-164. [CrossRef]

22. Raworth, K. Doughnut Economics: Seven Ways to Think Like a 21st Century Economist; Chelsea Green Publishing: London, UK, 2017.

23. Breuer, A.; Janetschek, H.; Malerba, D. Translating sustainable development goal (SDG) interdependencies into policy advice. Sustainability 2019, 11, 2092. [CrossRef]

24. Niestroy, I. How Are We Getting Ready? The 2030 Agenda for Sustainable Development in the EU and Its Member States: Analysis and Action so Far; Discussion Paper; German Development Institute/Deutsches Institut für Entwicklungspolitik (DIE): Bonn, Germany, 2016.

25. Nakicenovic, N.; Messner, D.; Zimm, C.; Clarke, G.; Rockstrom, J.; Aguiar, A.P.; Boza-Kiss, B.; Campagnolo, L.; Chabay, L.; Collste, D.; et al. TWI2050-The World in 2050 (2019). The Digital Revolution and Sustainable Development: Opportunities and Challenges; The World in 2050 Initiative; International Institute for Applied Systems Analysis (IIASA): Laxenburg, Austria, 2019.

26. Banerjee, B. Modern Slavery is an Enabling Condition of Global Neoliberal Capitalism: Commentary on Modern Slavery in Business; SAGE Publications: Los Angeles, CA, USA, 2021.

27. Rippingale, J. Consumers are Not Aware We Are Slaves inside the Greenhouses. 2019. Available online: https://www.aljazeera. $\mathrm{com} /$ features / 2019/10/16/ consumers-are-not-aware-we-are-slaves-inside-the-greenhouses (accessed on 6 September 2021).

28. Erneut 81 Corona-Fälle in Tönnies-Schlachthof, in Zeit Online. 2020. Available online: https://www.zeit.de/zustimmung? url=https $\% 3 \mathrm{~A} \% 2 \mathrm{~F} \% 2 \mathrm{Fwww}$.zeit.de $\% 2$ Fgesellschaft $\% 2$ Fzeitgeschehen $\% 2 \mathrm{~F} 2020-10 \% 2 \mathrm{Ftoennies}$-fleischindustrie-coronavirussoegel-ausbruch-schlachthof (accessed on 20 September 2021).

29. Arnold, M. Abattoir Coronavirus Outbreak Triggers Infections Surge in Germany, in FT. 2020. Available online: https://www.ft. com/content/057e861b-ef35-418d-9d16-81d2a0219212 (accessed on 6 September 2021).

30. NGG. Für die Fleischkonzerne Heiligt der Profit alle Mittel. Das Arbeitsschutzkontrollgesetz Muss eins zu eins Umgesetzt Werden. 2020. Available online: https:/ / www.ngg.net/presse/pressemitteilungen/2020/fuer-die-fleischkonzerne-heiligt-der-profitalle-mittel-das-arbeitsschutzkontrollgesetz-muss-eins-zu-eins-umgesetzt-werden/ (accessed on 20 September 2021).

31. Nordrhein-Westfalen, Alle Gegen Tönnies, in Süddeutsche Zeitung. 2020. Available online: https:/ / www.sueddeutsche.de/ politik/nordrhein-westfalen-alle-gegen-toennies-1.4946220 (accessed on 20 September 2021).

32. Connolly, K. Meat Plant Must be Held to Account for COVID-19 Outbreak, Says German Minister. 2020. Available online: https: //www.theguardian.com/world/2020/jun/22/meat-plant-must-be-held-to-account-covid-19-outbreak-germany (accessed on 4 October 2021).

33. Germany: Coronavirus Exposes Meat Workers' Plight, in DW. 2020. Available online: https://www.dw.com/en/germanycoronavirus-exposes-meat-workers-plight/a-53902174 (accessed on 7 September 2021).

34. Oltermann, P. German Police Raid Meat-Processing Firms Suspected of Smuggling Workers, in Guardian. 2020. Available online: https://www.dw.com/en/german-police-raid-meat-industry-firms-over-illegal-workers/a-55022253 (accessed on 6 September 2021).

35. Klassen, R.D.; Vereecke, A. Social issues in supply chains: Capabilities link responsibility, risk (opportunity), and performance. Int. J. Prod. Econ. 2012, 140, 103-115. [CrossRef]

36. Alghababsheh, M.; Gallear, D. Socially sustainable supply chain management and suppliers' social performance: The role of social capital. J. Bus. Ethics 2021, 173, 855-875. [CrossRef]

37. ILO. The Rana Plaza Accident and Its Aftermath. 2018. Available online: https://www.ilo.org/global/topics/geip/WCMS_6143 94/lang--en/index.htm (accessed on 5 September 2021).

38. Davies, R.; Kelly, A. More than $£ 1$ bn Wiped Off Boohoo Value as It Investigates Leicester Factory, in Gaurdian. 2020. Available online: https:/ /www.theguardian.com/business/2020/jul/06/boohoo-leicester-factory-conditions-covid-19 (accessed on 6 September 2021).

39. Sanders, L. Leicester Lockdown Unveils the Truth about Its Fast Fashion Industry, in Euronews. 2020. Available online: https: //www.euronews.com/culture/2020/07/12/leicester-lockdown-unveils-the-truth-about-its-fast-fashion-industry (accessed on 6 September 2021).

40. Miklós, A. Exploiting injustice in mutually beneficial market exchange: The case of sweatshop labor. J. Bus. Ethics 2019, 156, 59-69. [CrossRef]

41. Rybarczyk, K. Ending Child Labor in Mica Mines in India and Madagascar. 2021. Available online: https://stopchildlabor.org/ ending-child-labor-in-mica-mines-in-india-and-madagascar/ (accessed on 6 September 2021).

42. Bernacchio, C. Virtue beyond contract: A MacIntyrean approach to employee rights. J. Bus. Ethics 2021, 171, 227-240. [CrossRef] 
43. Matthews, A. SLAVE LABOUR Your Groceries Picked by Slaves-How Britain's Biggest Slavery Gang Supplied Supermarkets such as Tesco, Asda and M\&S, in Sun. 2019. Available online: https://www.thesun.co.uk/news/9454633/your-groceries-picked-byslaves-how-britains-biggest-slavery-gang-supplied-supermarkets-such-as-tesco-asda-and-ms / (accessed on 6 September 2021).

44. Dawkins, C.E. A normative argument for independent voice and labor unions. J. Bus. Ethics 2019, 155, 1153-1165. [CrossRef]

45. Martin-Ortega, O.; Outhwaite, O.; Rook, W. Buying power and human rights in the supply chain: Legal options for socially responsible public procurement of electronic goods. Int. J. Hum. Rights 2015, 19, 341-368. [CrossRef]

46. Gualandris, J.; Klassen, R.; Vachon, S.; Kalchsmidt, M.G.M. Sustainable evaluation and verification in supply chains: Aligning and leveraging accountability to stakeholders. J. Oper. Manag. 2015, 38, 1-13. [CrossRef]

47. Mares, R. The limits of supply chain responsibility: A critical analysis of corporate responsibility instruments. Nord. J. Int. Law 2010, 79, 193-244. [CrossRef]

48. Kelly, A. Primark and Matalan among Retailers Allegedly Cancelling £2.4bn Orders in 'Catastrophic' Move for Bangladesh, in Guardian. Available online: https:/ / www.theguardian.com/global-development/2020/apr/02/fashion-brands-cancellationsof-24bn-orders-catastrophic-for-bangladesh (accessed on 6 September 2021).

49. Mosley, L. Workers' rights in global value chains: Possibilities for protection and for peril. New Political Econ. 2017, 22, 153-168. [CrossRef]

50. Chi, T. Building a sustainable supply chain: An analysis of corporate social responsibility (CSR) practices in the Chinese textile and apparel industry. J. Text. Inst. 2011, 102, 837-848. [CrossRef]

51. Sarfaty, G.A. Shining light on global supply chains. Harv. Int. J. 2015, 56, 419.

52. Feinmann, J. The scandal of modern slavery in the trade of masks and gloves. BMJ 2020, 369, m1676. [CrossRef]

53. Locke, R.M. The Promise and Limits of Private Power: Promoting Labor Standards in a Global Economy; Cambridge University Press: Cambridge, MA, USA, 2013.

54. Sovacool, B.K. When subterranean slavery supports sustainability transitions? power, patriarchy, and child labor in artisanal Congolese cobalt mining. Extr. Ind. Soc. 2021, 8, 271-293. [CrossRef]

55. Grosser, K.; Tyler, M. Sexual Harassment, Sexual Violence and CSR: Radical Feminist Theory and a Human Rights Perspective. J. Bus. Ethics 2021, 1-16. [CrossRef]

56. Cundy, A. How to Make Business Fix Supply Chain Flaws, in FT. 2020. Available online: https://www.ft.com/content/8f03f397 -d36f-467c-8907-98beb5ce9e9c (accessed on 6 September 2021).

57. Boström, M.; Pati, R.K.; Padhi, S.; Govindan, K. Sustainable and responsible supply chain governance: Challenges and opportunities. J. Clean. Prod. 2015, 107, 1-7. [CrossRef]

58. Reuters. Horizontal Collaboration in Response to Modern Slavery Legislation: An Action Research Project Peyton, N. West African Countries on Alert for Child Labor Spike Due to Coronavirus. 2020. Available online: https://www.reuters.com/article/ us-health-coronavirus-westafrica-traffic-idUSKBN22C2KI (accessed on 6 September 2021).

59. Rajeev, A.; Pati, R.K.; Padhi, S.; Govindan, K. Evolution of sustainability in supply chain management: A literature review. J. Clean. Prod. 2017, 162, 299-314. [CrossRef]

60. Harvey, D. A Brief History of Neoliberalism; Oxford University Press: Oxford, UK, 2007.

61. Venkatesan, R. The UN Framework on Business and Human Rights: A workers' rights critique. J. Bus. Ethics 2019, 157, 635-652. [CrossRef]

62. Ketokivi, M.; Choi, T. Renaissance of case research as a scientific method. J. Oper. Manag. 2014, 32, 232-240. [CrossRef]

63. Pratt, M.G. From the editors: For the lack of a boilerplate: Tips on writing up (and reviewing) qualitative research. Acad. Manag. J. 2009, 52, 856-862. [CrossRef] 